\title{
Political Marketing, Word of Mouth Communication and Voter Behaviours Interaction*
}

\author{
Resul Ozturk ${ }^{\mathrm{a}}$, Suzan Coban ${ }^{\mathrm{b}}$
}

Abstract: Political actors aim at persuading voters, who are the key elements of target market in order to win election by gaining a higher vote potential than their opponents. Whether voter preferences are shaped by political elements or by the effects of social environment has become the focus of the studies within the relevant literature. The main purpose of this study is to determine the effect of political marketing activities and word of mouth communication and to determine mediator role WOM communication on voter behaviours. The study is conducted in Konya on a sample consisting of 432 voters and the size of which is determined by convenience sampling method by using face-to-face survey method. Political marketing, word of mouth communication and voter behaviours are confirmed by structural equation modelling through confirmatory factor analysis. As a result of the study, political marketing activities and word of mouth communication are found to have a positive effect on voter behaviour. Furthermore, it is determined that word of mouth communication have mediator role in the effect of political marketing activities on voter behaviours.
Keywords: Political Marketing, Word of Mouth Communication, Voter Behaviours

JEL: M31, D72

Received : 12 November 2018 Revised : 05 December 2018 Accepted : 17 December 2018 Type : Research

\section{Introduction}

Political marketing is an interdisciplinary concept that is influenced by politics, marketing and communication and examines political parties and voter behaviour (Scammell, 1999: 718). Political marketing emerges when political actors start using marketing concepts and theories in the analysis of political activities (Henneberg \& O’Shaughnessy, 2009: 7).

Political marketing involves the analysis, development, implementation and management of strategic campaigns to achieve the goals of directing the public opinion to meet the needs and desires of the target voter groups, promoting party ideologies, winning elections, making law and referendums (Winchester, Hall \& Binney, 2016: 260). More specifically, political marketing includes all of the techniques used to ensure the candidate/leader's compliance with potential voters, to promote political actors to as much voters as possible, to get ahead of the competitors and the opposition, to win a campaign with minimum tools, and to obtain the number of votes required (Orel \& Nakiboğlu, 2010: 65). Political marketing is considered as a set of processes starting from voter analysis and including the development of the most appropriate political products, covering proper pricing, efficient distribution, and effective promotion to meet the needs of target voter groups (Polat \& Kütler, 2008: 6). According to the definition, it can be said

a Asst.Prof., PhD., Necmettin Erbakan University, Faculty Of Applied Sciences, Management Information Systems, resulozturk@konya.edu.tr (ORCID ID: 0000-0003-1493-7315)

b Assoc. Prof., PhD., Nevşehir Hacı Bektaş Veli University, Faculty of Economics and Administrative Sciences, Business Administration, suzan@nevsehir.edu.tr (ORCID ID: 0000-0002-0723-5895) 
that the point of action in political marketing activities is the analysis of voter and voting behaviour in today's political marketing perspective. This means the adoption of a market-oriented perspective. Political actors can bring new horizons to their political marketing activities as long as they perceive voters as consumers and pay attention to establish and maintain a long-lasting sincere relationship with them (Reeves \& De Chernatony, 2009). Therefore, being in an interactive relationship with voters and other target masses during the preparation and implementation of policies is inevitable for success in political marketing (Beznosov, 2007: 52). To maintain good communication with the target voter groups, one of the communication methods out of many for political actors to reach their goals is word-of-mouth (WOM) communication. To ensure positive and strong word-of-mouth communication will mainly depend on the efforts of political actors.

Word-of-mouth communication in traditional marketing is a concept that is used to spread commercial products or services among consumers and is regarded as a promotional tool in the literatüre (Argan \& Argan, 2012: 71). The concept of word-of-mouth communication is defined as interpersonal advice and oral communication (Goyette, Ricard, Bergeron \& Marticotte, 2010: 6). Word-of-mouth communication is the cornerstone of powerful marketing tool which is word-of-mouth marketing (Groeger \& Buttle, 2014) and is expressed as a form of communication based on interpersonal and social interaction in which consumers exchange ideas about their experiences (Liang, Ekinci, Occhiocupo \& Whyatt, 2013).

The importance of word-of-mouth communication is increasing day by day because of voters' voting decisions as well as disappearance of their ambiguity in their votes and provides a safer flow of information through experience. According to Kırım (2007), the most convincing communication method about a product/service is the convincing advice by people who used or heard the usage of this product/service to their immediate surroundings. In this respect, voting behaviour of voters will be affected by the positive and/or negative recommendations of the voters of any party for potential and existing voters in their voting, re-voting or decision changing behaviours. One of the reasons why word-of-mouth communication is important in political marketing is the fact that political marketers have the least reliability among all marketers (Adams, Ezrow \& Topcu, 2011). On the other hand, a small number of voters believe in political marketing messages (messages conveyed through communication techniques such as advertising, sales promotion) that are spoken/advocated (Hopkins, 2013; Van Steenburg, 2015). In such a case, WOM messages passing through the correct communication channel and effective group members can be more convincing and reliable than classical methods, and they have the power on voter's behaviour to change their mind through different political parties (lyer, Yazdanparast \& Strutton, 2017).

Waller (1995) pointed out in his work that traditional communication models are insufficient to explain political communication. Within the scope of his research, he proposed a new model for political communication by expressing that there are more than one recipient and source in the process of political communication instead of a single recipient and a single source in traditional communication models. Additionally, in this proposed model, he argued that voters' voting behaviour is influenced by other voters and political actors in the process of political communication. In this context, it is theoretically expressed that voters who are interacting with the other voters and they are knowledgeable about politics have an influence on the voter's voting decision (O'Cass \& Pecotich, 2005: 406-407), in other words, word-of-mouth communication affect the voter behaviour.

In light of these information, when the political marketing literature is examined, it is thought that word-of-mouth communication techniques are important in terms of increasing the efficiency of political marketing. Moreover, in the literature, there is limited number of studies evaluating the use of word-ofmouth communication in political marketing from different aspects (Güler \& Ülker, 2010; Argan \& Argan, 2012; lyer et al., 2017) and most of these studies focus especially on e-WOM recently (O'Cass \& Pecotich, 2005; Richey, 2008; Skoric, 2012; Gülsünler, 2014; Van Steenburg, 2015; Iyer et al., 2017;). Although there are works in the literature which studied the effects of political marketing activities and word-of-mouth communication techniques on voter behaviour, there is no practical study found which intent to measure the mediating effect. From this point of view, it is thought that this study will make an important contribution to the literature. 


\section{The Purpose, Models and Hypotheses of The Research}

The purpose of this study is to determine the mediating role of word-of-mouth communication in the effect of political marketing activities towards voter behaviour. The other aims are to explain the effects of political marketing activities and word-of-mouth communication on voter behaviour. In this context, model of this study is shown in Figure 1. below.

Figure 1. Research Model

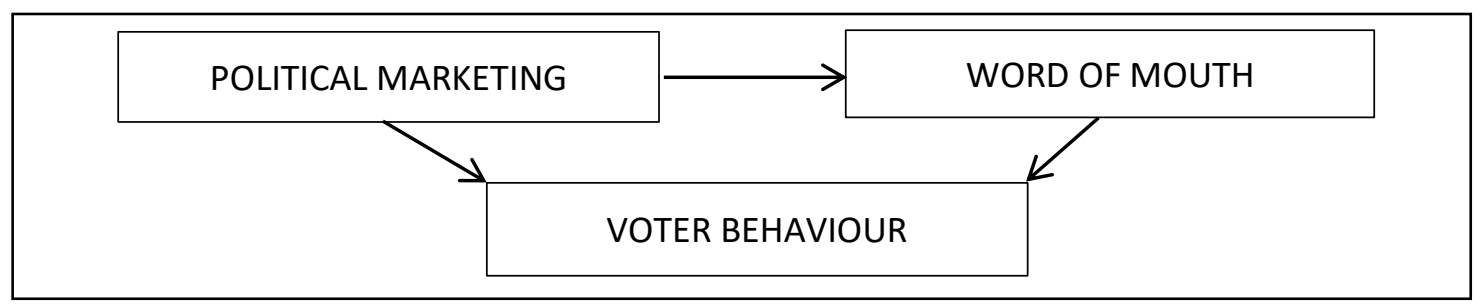

Based on the research objectives and considering the conceptual framework, the hypotheses developed for this research are listed below.

$H_{1}$ : Political marketing has a statistically significant effect on voter behaviour.

$\mathrm{H}_{2}$ : Political marketing has a statistically significant effect on word-of-mouth communication.

$H_{3}$ : Word-of-mouth communication has a statistically significant effect on voter behaviour.

$\mathrm{H}_{4}$ : Word-of-mouth communication has a mediating effect on the interaction between political marketing and voter behaviour.

\section{Research Methodology}

\subsection{Method of Data Collection}

Data collections are fundamental for researches and in this research both primary and secondary (documentary) data as a source have been used. In the acquisition of the primary data, the survey method was used and the survey was conducted through face-to-face interviews. In the creation of questionnaire form, the questionnaires in the literature about political marketing, word-of-mouth communication and voter behaviour were evaluated. Most of the items in the questionnaire form are taken off the previous related studies. In addition to these items, new items were developed and these new items were scaled according to the literature. The following resources were used in the development of items of the questionnaire:

- Political Marketing: The political marketing scale designed to determine the political marketing activities conducted by political actors is considered in four dimensions as political product, political price, political place and political promotion. In this framework, various studies have been used (Kotler, 1975; Niffenegger, 1989; Çiftlikçi, 1996; Lock \& Harris, 1996; Wring, 1997; Tan, 1998; Harris, 2001; LeesMarshment, 2001; Baines, Harris \& Lewis, 2002; İslamoğlu, 2002; O'Cass, 2002; Tan, 2002; Baines, Brennan \& Egan, 2003; Henneberg, 2004; Polat, Gürbüz \& Inal, 2004; Divanoğlu, 2007; Akyüz, 2015; Polat, 2015). Therefore, political marketing activities conducted by political parties were tried to be determined. All items are based on the 5-point Likert scale graded from 1 "Strongly Disagree" (coded as 1 ) to 5 "Strongly Agree" (coded as 5).

- Word-of-Mouth Communication: The word-of-mouth communication scale established by voters for political marketing activities has three dimensions as recommendation, taking advice and communication structure and in this framework; it has been benefited from various studies (Feick \& Price, 1987; Podoshen, 2008; Goyette et al., 2010; Yılmaz, 2011; Çaylak \& Tolon, 2013; Özyer, 2015). Likewise, these items are also in the form of 5-point Likert scale. 
- Voter Behaviour: The voter behaviour scales developed to determine the voting behaviour of the people are considered in three dimensions as sociological, socio-psychological and rational/economic voting. In the development of the scale of voter behaviour, studies by Kalender (2005), Heywood (2006), Cwalina et al. (2011) and Boyraz (2012) were used. All items in the questionnaire that were answered by participants were formed as 5-point Likert Scale graded from 1 "Strongly Disagree" (coded as 1) to 5 "Strongly Agree" (coded as 5).

\subsection{Selection of Sampling and Determination of Sampling Method}

The universe of the research was determined as voters registered with the province of Konya. However, the lists contain personal information of voters, sampling framework could not be determined because they are not shared publicly by selection boards. For this reason, the non-probability sampling method is used. In this study, convenience sampling method is preferred because of its easy implementation in research design, and it is also less costly and not time consuming.

It is accepted sufficiently that the sample size can be taken as 384 when the universe of the research is one million or more as well as when the confidence interval is at 0.05 levels (Sekaran, 2003: 294). In the research, it was aimed to determine a sample size that can allow generalization on the universe. In this respect, voters aged 18 and above attained to the 26. Period General Elections in the province of Konya dated November 1, 2015 and numbers determined by the Supreme Election Council in Turkey as 1,436,847 people (http://www.ysk.gov.tr/ysk). When taking into account the same election results, it was determined that the number of registered voters in Konya city centre is 811,052 (http://www.ysk.gov.tr/ysk). Since there has not been a new election since the date of the survey, there is no information if there is any change in the number of the voters. Within the scope of the study, 500 surveys were conducted to the people registered in Konya city centre. 40 of the questionnaires were found to be inappropriate for analysis and 28 of them were not returned therefore, 68 surveys were taken off from the total number of surveys. A total of 432 questionnaires were obtained which were suitable for evaluation as a result of the survey implementation. In this context, the rate of return obtained is about $86.4 \%$ and the sample distribution is shown in Table 1.

Table 1. Demographic Characteristics of Participants

\begin{tabular}{|c|c|c|c|c|c|c|c|}
\hline & & $f$ & $\%$ & & & $f$ & $\%$ \\
\hline \multirow{2}{*}{ Gender } & Female & 167 & 38.7 & \multirow{5}{*}{ Income } & $1,500 €$ and under & 114 & 26.4 \\
\hline & Male & 265 & 61.3 & & 1,501も-2,500も & 124 & 28.7 \\
\hline \multirow{8}{*}{ Age } & $18-25$ & 96 & 22.2 & & $2,501 も-3,500 も$ & 91 & 21.1 \\
\hline & $26-35$ & 187 & 43.3 & & $3,501 も-4,500 も$ & 62 & 14.4 \\
\hline & $36-45$ & 80 & 18.5 & & $4,501 €$ and over & 41 & 9.5 \\
\hline & \multirow{2}{*}{$46-55$} & \multirow{2}{*}{37} & \multirow{2}{*}{8.6} & \multirow{5}{*}{ Education } & Literate & 6 & 1.4 \\
\hline & & & & & Primary & 56 & 13.0 \\
\hline & \multirow{2}{*}{$56-65$} & \multirow[b]{2}{*}{26} & \multirow{2}{*}{6.0} & & High School & 96 & 22.2 \\
\hline & & & & & Vocational & 47 & 10.9 \\
\hline & 66 years and over & 6 & 1.4 & & Undergraduate & 178 & 41.2 \\
\hline Marital & Married & 288 & 66.7 & & Postgraduate & 49 & 11.3 \\
\hline Status & Single & 144 & 33.3 & & Total & 432 & 100 \\
\hline
\end{tabular}

\subsection{Methods Used in Data Analysis}

In this study, structural equation modelling was used 248 ort he analysis of data collected. SPSS AMOS (Analysis of Moment Structures) program was used 248ort he structural equation modelling. Exploratory factor analysis was first performed in the study by using SPSS program and then confirmatory factor analysis was applied to test the results. Finally, structural equation modelling is used for hypothesis testing. The information in Table 2 was used to interpret the results of the analysis (Karagöz, 2016: 975). 
Table 2. Structural Equation Modelling Goodness of Fit Indices

\begin{tabular}{|c|c|c|}
\hline Fit Indices & Good Fit Indices & Acceptable Fit Indices \\
\hline$\chi^{2}$ Fit Index & $1 \geq p>0.05$ & $0.05 \geq p>0.01$ \\
\hline CMIN/SD & $\chi^{2} / s d \leq 3$ & $\chi^{2} / s d \leq 5$ \\
\hline \multicolumn{3}{|c|}{ Comparative Fit Indices } \\
\hline $\mathrm{NFI}$ & $\mathrm{NFI} \geq 0.95$ & $\mathrm{NFI} \geq 0.90$ \\
\hline TLI (NNFI) & $\mathrm{NNFI} \geq 0.95$ & $\mathrm{NNFI} \geq 0.90$ \\
\hline IFI & $|F| \geq 0.95$ & $|F| \geq 0.90$ \\
\hline CFI & $\mathrm{CFI} \geq 0.95$ & $\mathrm{CFI} \geq 0.90$ \\
\hline RMSEA & RMSEA $\leq 0.05$ & RMSEA $\leq 0.08$ \\
\hline \multicolumn{3}{|c|}{ Absolute Fit Indices } \\
\hline GFI & $\mathrm{GFI} \geq 0.90$ & $\mathrm{GFI} \geq 0.85$ \\
\hline AGFI & AGFI $\geq 0.90$ & $A G F I \geq 0.85$ \\
\hline \multicolumn{3}{|c|}{ Parsimony Fit Indices } \\
\hline PNFI & $\mathrm{PNFI} \geq 0.95$ & - \\
\hline PGFI & PGFI $\geq 0.95$ & - \\
\hline \multicolumn{3}{|c|}{ Incremental Fit Indices } \\
\hline RMR & $0<\mathrm{RMR} \leq 0.05$ & $0<\mathrm{RMR} \leq 0.08$ \\
\hline SRMR & $0<\mathrm{SRMR} \leq 0.05$ & $0<\mathrm{SRMR} \leq 0.08$ \\
\hline
\end{tabular}

\section{Findings}

\subsection{Results of Confirmatory Factor Analysis}

The proposed measurement model data were tested for construct validity using confirmatory factor analysis. The measurement model including 102 items describing 13 latent construct: PRD, PRC, PLC, PRM, REC, TA, INT, PV, NV, CON, SPS, SOC, RE. The initial test of the measurement model were made construct revisions. After revisions of measurement model, 60 items were retained. The test of final measurement model demostrated a good fit between the data and the purposed measurement model. Construct validity values of each scales are given in Table 3 .

Table 3. Construct Validity of Scales

\begin{tabular}{|c|c|c|c|c|c|}
\hline Scales & Dimensions & Sub-dimensions & $\begin{array}{l}\text { Total } \\
\text { Items }\end{array}$ & $\begin{array}{l}\text { Removed } \\
\text { Items }\end{array}$ & $\begin{array}{l}\text { Hold } \\
\text { Items }\end{array}$ \\
\hline \multirow{4}{*}{$\begin{array}{l}\text { Political Marketing } \\
\text { (PM) }\end{array}$} & Product (PRD) & & 15 & 4 & 11 \\
\hline & Price (PRC) & & 5 & 2 & 3 \\
\hline & Place (PLC) & & 3 & 0 & 3 \\
\hline & Promotion (PRM) & & 13 & 7 & 6 \\
\hline \multirow{6}{*}{$\begin{array}{l}\text { Word of Mouth } \\
\text { Communication } \\
\text { (WOM) }\end{array}$} & Recommendation (REC) & & 9 & 5 & 4 \\
\hline & Taking Advice (TA) & & 14 & 6 & 8 \\
\hline & \multirow{4}{*}{ Communication (COM) } & Intensity (INT) & 2 & 0 & 2 \\
\hline & & Positive Valence (PV) & 3 & 0 & 3 \\
\hline & & Negative Valence (NV) & 3 & 0 & 3 \\
\hline & & Content (CON) & 4 & 1 & 3 \\
\hline \multirow{4}{*}{ Voter Behaviour (VB) } & Sociopsychological (SPS) & & 10 & 5 & 5 \\
\hline & Sociological (SOC) & & 10 & 6 & 4 \\
\hline & Rational / Economic (RE) & & 11 & 6 & 5 \\
\hline & TOTAL & & 102 & 42 & 60 \\
\hline
\end{tabular}


As a result of confirmatory factor analysis, goodness of fit values of scales are given in Table 4. According to goodness of fit values of scales, reliability values of scale and sub-dimensions are shown in Table 5 .

Table 4. Goodness of Fit Values

\begin{tabular}{lcccccc}
\hline \multicolumn{1}{c}{ Variable } & $\mathbf{X}^{\mathbf{2}}$ & df & $\mathbf{X}^{2} / \mathbf{d f}$ & GFI & CFI & RMSEA \\
\hline Political Marketing & 525.86 & 226 & 2.32 & 0.90 & 0.93 & 0.06 \\
Word of Mouth Communication & 528.76 & 182 & 2.90 & 0.90 & 0.93 & 0.07 \\
Voter Behaviour & 243.37 & 74 & 3.29 & 0.93 & 0.93 & 0.07 \\
Good Fit & & & $\leq 3$ & $\geq 0.90$ & $\geq 0.95$ & $\leq 0.05$ \\
Acceptable Fit & & & $\leq 4-5$ & $\mathbf{2 0 . 8 5}$ & $\mathbf{2 0 . 9 0}$ & $\leq 0.08$ \\
\hline
\end{tabular}

Table 5. Cronbach's Alpha Values

\begin{tabular}{lclc}
\hline \multicolumn{1}{c}{ Dimensions } & $\begin{array}{c}\text { Dimensions } \\
\text { Cranbach's Alfa }\end{array}$ & \multicolumn{1}{c}{ Sub-dimensions } & $\begin{array}{c}\text { Sub-dimensions } \\
\text { Cronbach's Alfa }\end{array}$ \\
\hline \multirow{3}{*}{ Political Marketing (PM) } & \multirow{3}{*}{$\mathbf{0 . 8 9 8}$} & Product (PRD) & 0.896 \\
& & Price (PRC) & 0.760 \\
& & Place (PLC) & 0.823 \\
& & Promotion (PRM) & 0.868 \\
\hline \multirow{3}{*}{ Word of Mouth } & & Recommendation (REC) & 0.777 \\
Communication (WOM) & \multirow{3}{*}{$\mathbf{0 . 9 4 4}$} & Taking Advice (TA) & 0.868 \\
& & Intensity (INT) & 0.812 \\
& & Positive Valence (PV) & 0.846 \\
& & Negative Valence (NV) & 0.738 \\
Voter Behaviour (VB) & & Content (CON) & 0.854 \\
& \multirow{3}{*}{$\mathbf{0 . 8 6 1}$} & Sociopsychological (SPS) & 0.801 \\
& & Sociological (SOC) & 0.747 \\
& & Rational / Economic (RE) & 0.816 \\
\hline
\end{tabular}

In this line, construct validity and reliability findings of variables are explained in below:

- Political Marketing Mix: In the structural equation modelling, confirmatory factor analysis was carried out separately on all of the product, price, place and promotion dimensions in order to measure path analysis and mediation effect. As a result of confirmatory factor analysis for political marketing scale, it was determined that the goodness of fit values were significant and within acceptable limits $(p<0.05)$. The goodness of fit values for political marketing dimension is shown in Table 4. In addition, the validity values of the items are shown in Table 5. When the values in Table 5 are examined, it can be seen that the political marketing scale $(0.898)$ is reliable at a high level $(\alpha>0.70)$. When the results of the analysis are evaluated, it can be concluded that the political marketing scale has internal consistency and provides structural validity.

- Word-of-Mouth Communication: In the structural equation model, in order to measure the path analysis and mediation effect, dimensions of word-of-mouth communication were grouped as recommendation, advice, intensity, positive valence, negative valence and content. As a result of confirmatory factor analysis for word-of-mouth communication dimensions, values of goodness of fit are significant and within the acceptable limits $(p<0.05)$ shown in Table 4 . In addition, reliability values are given in Table 5. When looking at the values in Table 5, it can be determined that the word-of-mouth communication scale $(0.944)$ is reliable at high level $(\alpha>0.70)$. When the results of 
the analysis are evaluated, it can be concluded that the word-of-mouth communication scale has internal consistency and it provides structure validity.

- Voter Behaviour: In the structural equation model, confirmatory factor analysis has been applied to the all dimensions of voter behaviour which are socio-psychological, sociological and rational/economic voting to be able to reach significant compliance values. In this respect, confirmatory factor analysis with the best goodness of fit values can be found significant and within acceptable limits $(p<0.05)$. The values of goodness of fit for voter behaviour are shown in Table 4 . Additionally, when the values in Table 5 are examined, it can be said that the voter behaviour scale $(0.861)$ is reliable at a high level $(\alpha>0.70)$. When looking at the overall results, voter behaviour scale can be concluded as it has the internal consistency and it provides structural validity.

\subsection{Testing Hypothesis}

In the context of the structural equation model, the mediation model proposed by Baron and Kenny (1986) was used to determine the mediating role of word-of-mouth communication on voter behaviour and political marketing. The first phase of the model shows that the changes in the independent variable explain the reasons on changes in the predicted mediating variable significantly. In the second phase, the changes in the mediating variable should explain the reasons for changes in the dependent variable significantly. In the third phase of the model, the relationship between the independent variable and the mediator variable; the mediator variable and the dependent variable is under control, if the previous significant relationship between the dependent and independent variables becomes insignificant, it can be full mediation effect. However, under the same control, if the relationship between dependent and independent variable decreases, it can be partial mediation effect (Baron \& Kenny, 1986: 1176). Within the scope of the research, political marketing as an independent variable, voter behaviour as a dependent variable and word-of-mouth communication as a mediator variable have been considered. In addition, the Sobel test was used to determine the mediating effect.

As a result of the structural equation model, the effects of the variables on each other and the goodness fit values and the coefficients of structural equation model are given in Table 6 and Table 7.

Table 6. Structural Equation Model Goodness of Fit Values

\begin{tabular}{lcccccc}
\hline \multicolumn{1}{c}{ Variables } & $\mathbf{X}^{\mathbf{2}}$ & $\mathbf{d f}$ & $\mathbf{X}^{\mathbf{2}} \mathbf{d f f}$ & GFI & CFI & RMSEA \\
\hline Political Marketing - Voter Behaviour & $1,218.00$ & 586 & 2.07 & 0.86 & 0.91 & 0.05 \\
Political Marketing - Word of Mouth & $1,655.72$ & 807 & 2.05 & 0.85 & 0.91 & 0.05 \\
Word of Mouth - Voter Behaviour & $1,245.06$ & 516 & 2.41 & 0.85 & 0.91 & 0.06 \\
Good Fit & & & $\leq 3$ & $\geq \mathbf{0 . 9 0}$ & $\mathbf{2 0 . 9 5}$ & $\leq \mathbf{0 . 0 5}$ \\
Acceptable Fit & & & $\leq \mathbf{4}-\mathbf{5}$ & $\mathbf{2 0 . 8 5}$ & $\mathbf{\geq 0 . 9 0}$ & $\leq \mathbf{0 . 0 8}$ \\
\hline
\end{tabular}

Table 7. Structural Equation Model Coefficients

\begin{tabular}{lcccc}
\hline \multicolumn{1}{c}{ Variables } & Standardize $\boldsymbol{\beta}$ & $\begin{array}{c}\text { Standart } \\
\text { Error }\end{array}$ & $\mathbf{p}$ & $\mathbf{R}^{\mathbf{2}}$ \\
\hline Political Marketing - Voter Behaviour & 0.68 & 0.628 & $* * *$ & 0.47 \\
Political Marketing - Word of Mouth & 0.59 & 0.485 & $* * *$ & 0.35 \\
Word of Mouth - Voter Behaviour & 0.82 & 0.082 & $* * *$ & 0.67 \\
\hline
\end{tabular}

- The Effect of Political Marketing on Voter Behaviour: The goodness of fit values of the $\mathrm{H}_{1}$ hypothesis developed within the scope of the research is shown in Table 6 . The values in the table provide sufficient evidence that the goodness of fit values of the generated model is within acceptable limits and that the model is structurally appropriate. According to the developed model, standardized $\beta$ 
coefficients, standard error, $p$ and $R^{2}$ values between the variables are shown in Table 7 . When the values in Table 10 are examined, it can be seen that political marketing effects voter behaviour $(\beta=0.68 ; p<0.05)$. In the light of this finding, it can be said that political marketing activities have a significant effect on voter behaviour. When the Squared Multiple Correlations $\left(R^{2}\right)$ value of the model is examined, it is seen that $47 \%$ of voter behaviour is explained by political marketing.

- The Effect of Political Marketing on Word-of-Mouth Communication: The goodness of fit values of the $\mathrm{H}_{2}$ hypothesis developed within the scope of the research is shown in Table 6 . The values in the table provide sufficient evidence that the goodness of fit values of the generated model is within acceptable limits and that the model is structurally appropriate. According to the developed model, standardized $\beta$ coefficients, standard error, $p$ and $R^{2}$ values between the variables are shown in Table 7. When the values in Table 7 are examined, it can be seen that political marketing effects word-ofmouth communication $(\beta=0.59 ; p<0.05)$. In light of this finding, the $\mathrm{H}_{2}$ hypothesis, "Political marketing has a statistically significant effect on word-of-mouth communication." was supported within the scope of the research. When the Squared Multiple Correlations $\left(R^{2}\right)$ value of the model is examined, it is seen that $35 \%$ of word-of-mouth communication is explained by political marketing.

- The Effect of Word-of-Mouth Communication on Voter Behaviour: The goodness of fit values of the $\mathrm{H}_{3}$ hypothesis developed within the scope of the research is shown in Table 6 . The values in the table provide sufficient evidence that the goodness of fit values of the generated model is within acceptable limits and that the model is structurally appropriate. According to the developed model, standardized $\beta$ coefficients, standard error, $p$ and $R^{2}$ values between the variables are shown in Table 7. When the values in Table 7 are examined, it can be seen that the word-of-mouth communication effects voter behaviour $(\beta=0.82 ; p<0.05)$. In the light of this finding, it can be said that word-of-mouth communication has a statistically significant effect on voter behaviour. When the Squared Multiple Correlations $\left(R^{2}\right)$ value of the model is examined, it is seen that $67 \%$ of voter behaviour is explained by word-of-mouth communication.

\subsection{Mediation Role of Word-of-Mouth Communication in the Effect of Political Marketing on Voter}

\section{Behaviour}

The path analysis of the model with goodness of fit values is shown in Figure 2 . The fit statistics of the $\mathrm{H}_{4}$ hypothesis developed in this context are shown in Table 8. The statistics in the table provide sufficient evidence that the goodness of fit values of the generated model is within acceptable limits and that the model is structurally appropriate.

Table 8. Structural Equation Model Goodness of Fit Values - Mediation Role of Word-of-Mouth Communication on Voter Behaviour of Political Marketing

\begin{tabular}{|c|c|c|c|c|c|c|}
\hline Variables & $x^{2}$ & df & $\mathrm{X}^{2} / \mathrm{df}$ & GFI & CFI & RMSEA \\
\hline Political Marketing - Word of Mouth - Voter Behaviour & $1,745.74$ & 972 & 1.79 & 0.85 & 0.92 & 0.04 \\
\hline Good Fit & & & $\leq 3$ & $\geq 0.90$ & $\geq 0.95$ & $\leq 0.05$ \\
\hline Acceptable Fit & & & $\leq 4-5$ & $\geq 0.85$ & $\geq 0.90$ & $\leq 0.08$ \\
\hline
\end{tabular}

Structural equation model coefficients for the findings in $\mathrm{H}_{1}, \mathrm{H}_{2}$ and $\mathrm{H}_{3}$ hypotheses are given in Table 9 altogether. 
Table 9. Structural Equation Model Coefficients - Political Marketing - Word-of-Mouth Communication Voter Behaviour - Their Effects to Each Other

\begin{tabular}{lcccc}
\hline \multicolumn{1}{c}{ Variables } & Standardize $\boldsymbol{\beta}$ & $\begin{array}{c}\text { Standart } \\
\text { Error }\end{array}$ & $\mathbf{p}$ & $\mathbf{R}^{\mathbf{2}}$ \\
\hline Political Marketing - Voter Behaviour & 0.68 & 0.628 & $* * *$ & 0.47 \\
Word of Mouth - Voter Behaviour & 0.82 & 0.082 & $* * *$ & 0.67 \\
Political Marketing - Word of Mouth & 0.59 & 0.485 & $* * *$ & 0.35 \\
\hline
\end{tabular}

Standardized $\beta$ coefficients, standard error, $p$ and R2 values between the variables according to the generated model are shown in Table 10.

Table 10. Structural Equation Model Coefficients - Mediation Role of Word-of-Mouth Communication on Voter Behaviour of Political Marketing

\begin{tabular}{lcccc}
\hline \multicolumn{1}{c}{ Variables } & Standardize $\boldsymbol{\beta}$ & $\begin{array}{c}\text { Standart } \\
\text { Error }\end{array}$ & $\mathbf{p}$ & $\mathbf{R}^{\mathbf{2}}$ \\
\hline Political Marketing - Voter Behaviour & 0.36 & 0.419 & $* * *$ & \multirow{2}{*}{0.83} \\
Word of Mouth - Voter Behaviour & 0.65 & 0.086 & $* * *$ & .85 \\
Political Marketing - Word of Mouth & 0.60 & 0.549 & $* * *$ & 0.35 \\
\hline
\end{tabular}

When the findings of the research are examined, it can be seen that political marketing effects wordof-mouth communication $(\beta=0.60 ; p<0.05)$. In this case, since Baron and Kenny's (1986) second stage is fulfilled, the third stage was also tested for the determination of the mediating effect. When the mediator is included in the model and the relation between mediator variable and dependent variable is $p<0.05$, it can be concluded with the partial mediation affect because of the effect of independent variable on dependent variable $\beta$ coefficient decreases from 0.68 to 0.36 . In this case, it can be observed that the third phase of Baron and Kenny (1986) is also fulfilled. When looking at the value of Squared Multiple Correlations $\left(R^{2}\right)$ obtained from the model is examined, it can be seen that $35 \%$ of word-of-mouth communication is explained by political marketing and $83 \%$ of voter behaviour is explained by political marketing and word-of-mouth communication. According to the results of the Sobel test, the relationship between political marketing and voter behaviour is mediated by word-of-mouth communication (Sobel's SE=4.195, $p<0.01$ ). In the light of this finding, the $\mathrm{H}_{4}$ hypothesis, which is developed as "Word-of-mouth communication has a mediating effect on the interaction between political marketing and voter behaviour" is accepted within the scope of the research. 
Figure 2: Structural Equation Model - Mediation Role of Word-of-Mouth Communication on Voter Behaviour of Political Marketing

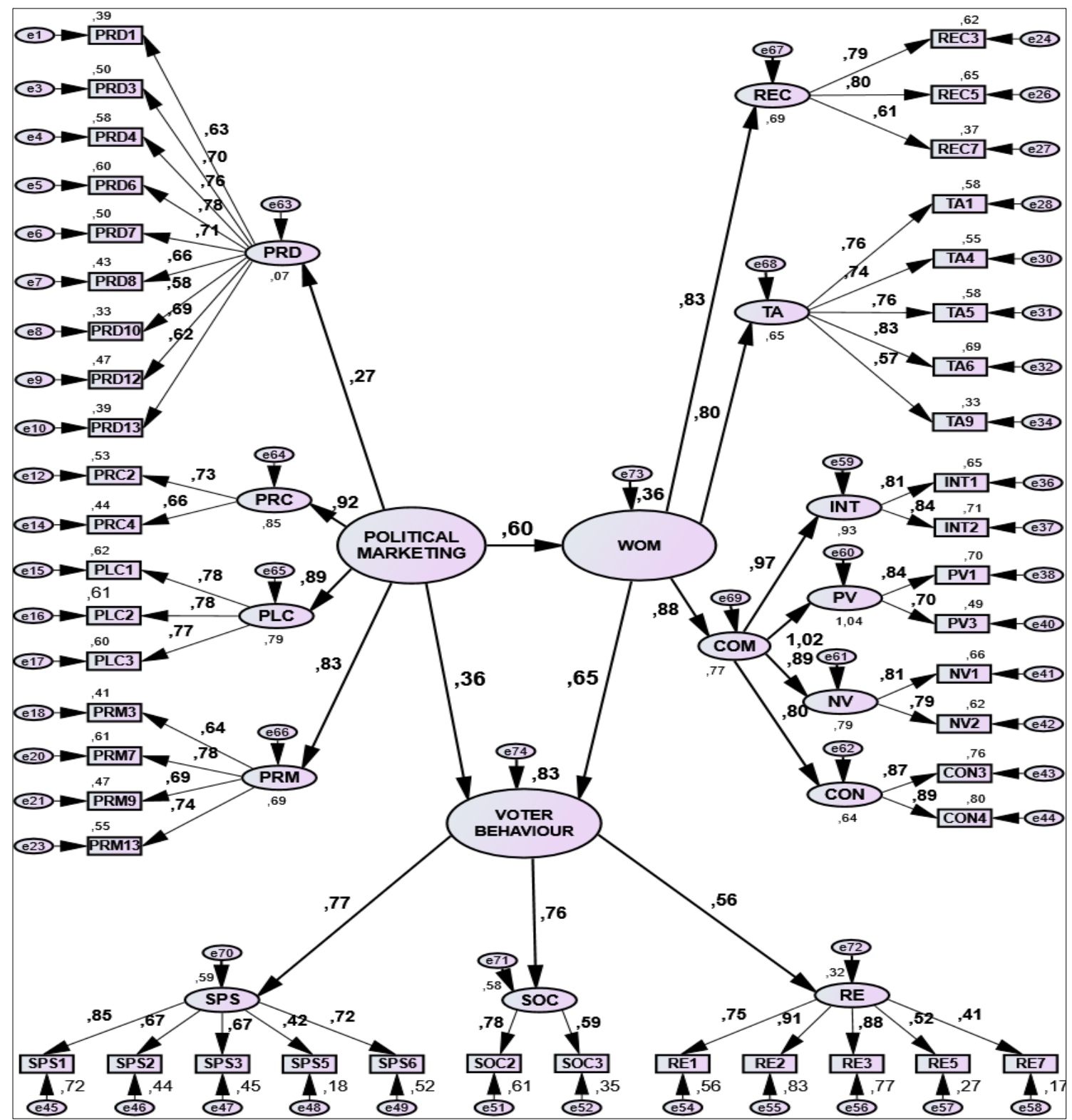

\section{Results}

The ultimate goal of political marketing activities for political actors is to win elections by receiving the support of the vast majority of voters. In this direction, it is necessary to establish the structure of political communication by analysing the factors effecting voter behaviour. With the development of technology, information on political activities is transmitted directly to voters via political actors, as well as this information reaches to the wider groups of voters by word-of-mouth communication techniques. Therefore, it becomes very important for the party and the candidate to ensure positive word-of-mouth communication.

The main purpose of this study is to determine the effect of political marketing activities and wordof-mouth communication techniques on voter behaviour, the effect of political marketing activities on wordof-mouth communication and to determine the mediating role of word-of-mouth communication in the effect of political marketing activities towards voter behaviour. Following findings can be drawn as a result of the research: 
- As a result of confirmatory factor analysis in the survey, it was determined that the political marketing mix scale was collected under four dimensions as product, place, price and promotion. Word-to-mouth communication scale emerges in three sub-dimensions as recommendation, taking advice and communication structure. The communication structure was determined with the four sub-dimensions which are intensity, positive valence, negative valence and content. Voter behaviours were found in three dimensions as socio-psychological voting, sociological voting and rational / economic voting. Results show that the dimensions obtained through the study are variables can explain the scales used in the research and the results are statistically significant.

- The effect of political marketing activities on voter behaviours was found statistically significant and positive $\left(p<0.05 ; \beta=0.68 ; R^{2}=0.47\right)$. These results and the previous studies in the literature show similarity.

- It was concluded that political marketing activities have a statistically significant effect on word-ofmouth communication $\left(p<0.05 ; \beta=0.59 ; R^{2}=0.35\right)$. Some studies in the literature have provided close results to the results of this research.

- A statistically significant effect of word-of-mouth communication on voter behaviour was found $\left(p<0.05 ; \beta=0.82 ; R^{2}=0.67\right)$ in the study. Similar research results have been obtained from various studies in the literature.

- Finally, the mediation effect of word-of-mouth communication were found in the effect of political marketing activities on voter behaviour $\left(p<0.05 ; \beta=0.36 ; \beta=0.65 ; R^{2}=0.83\right.$ ).

Overall results show that word-of-mouth communication has a partial mediation effect on voter behaviour. Therefore, the political marketing activities performed by political parties in order to influence voter behaviour become very important while they are also contributing to this process by being active in engaging positive word-of-mouth communication. In this regard, parties and/or candidates in addition to the modern marketing activities, they can be in a relationship marketing activities with voters which can trigger communication and provide appropriate ground for positive word-of-mouth communication. During the political marketing process, it can be important step to identify strong, popular, and recognized opinion leaders, to develop strong ties with them and to take advantage of these opinion leaders in campaigns to influence each target groups. In addition, providing high-level relationships with various social groups can ensure that the right messages are transmitted quickly towards voters. Word-of-mouth communication can be face to face or it can also be via phone, email or social media. In addition to classical methods, political actors should also use the web environment effectively and create an impressive communication network especially with fans or volunteers via e-mail, video or social media, enabling rapid sharing of messages that can allow rapid dissemination of receivers. In this context, it is necessary to utilize the technology especially for the $\mathrm{Y}$ and $\mathrm{Z}$ generation and to use the electronic word-of-mouth communication as the political marketing tool.

The following limitations must be taken into consideration in interpreting the results of the research. The first limitation is the universe and sampling method. In other words, voter lists could not be reached because of the personal information content, the non-random sampling method is chosen and the research have been done in Konya. The second limitation is the design and scale. The fact that other elements that may affect voter behaviour in the study are kept stable and that the questionnaire is formed by various studies can be an important limitation. In addition, the research is only evaluated with a given time period of data. Therefore, the findings must be interpreted within these limits.

As a recommendation, considering the questions asked in the research and the hypotheses put forward, it may be advisable to carry out on-going studies in future. Furthermore, when the limitations of the research are taken into consideration, similar or different samples can be studied in different geographical regions in future studies. Finally, in the light of information obtained as a result of this study, political relationship marketing can be taken as a new topic to discover. 


\section{End Notes}

* This article is derived from a PhD dissertation entitled "The Mediation Role of Word of Mouth Communication in the Effect of Political Marketing on Voter Behaviour: The Case of Konya", Hacı Bektaş Veli University Institute of Social Sciences, Business Administration Department on 31.03.2017.

\section{References}

Adams, J., Ezrow, L., \& Topcu, Z. (2011). Is anybody listening? Evidence that voters do not respond to european parties' policy statements during elections. American Journal of Political Science, 55(2), 370-382.

Akyüz, i. (2015). Siyasal pazarlama teorik bir çerçeve. İstanbul: Türkmen Kitabevi.

Argan, M., \& Argan, M. T. (2012). Word-of-mouth (wom): Voters originated communications on candidates during local elections. International Journal of Business and Social Science, 3(15), 70-77.

Baines, P.R., Harris, P., \& Lewis, B.R. (2002). The political marketing planning process: Improving image and message in strategic target areas. Marketing Intelligence \& Planning, 20(1), 6-14.

Baines, P. R., Brennan, R., \& Egan, J. (2003). Market classification and political campaigning: Some strategic implications. Journal of Political Marketing, 2(2), 47-66.

Baron, R. M., \& Kenny, D. A. (1986). The moderator-mediator variable distinction in social psychological research: Conceptual, strategic, and statistical considerations. Journal of Personality and Social Psychology, 51(6), 11731182.

Beznosov, M. A. (2007). Political markets of post-socialism: Anomalous development or evolutionary trend? The University of Arizona, Doctoral Dissertation, Arizona.

Boyraz, E. (2012). Stratejik siyaset pazarlaması ve siyaset pazarının bölümlendirilmesine ilişkin bir araştırma. Erciyes Üniversitesi Sosyal Bilimler Enstitüsü, Doktora Tezi, Kayseri.

Cwalina, W., Falkowski, A., \& Newman, B. I. (2011). Political marketing: Theoretical and strategic foundations. London: Routledge Inc.

Çaylak, P., \& Tolon, M. (2014). Ağızdan ağza pazarlama ve tüketicilerin ağızdan ağza pazarlamayı kullanımları üzerine bir araştırma. Iktisadi ve Idari Bilimler Fakültesi Dergisi, 15(3), 1-30.

Çiftlikçi, A. (1996). Siyaset pazarlaması ve siyasi partilerin malatya'daki uygulamaları. İnönü Üniversitesi Sosyal Bilimler Enstitüsü, Doktora Tezi, Malatya.

Demirtaş, M. C., \& Orçun, Ç. (2015). Siyasal pazarlama uygulamalarının ilk kez oy kullanacak seçmenler üzerindeki etkilerine yönelik bir araştırma. Karamanoğlu Mehmetbey Üniversitesi Sosyal ve Ekonomik Araştırmalar Dergisi, 2015(1), 41-48.

Divanoğlu, S. (2007). Seçim kampanyalarında milletvekili adaylarının ve partilerin kullandıkları pazarlama karması elemanları üzerine bir araştırma. Niğde Üniversitesi Sosyal Bilimler Enstitüsü, Doktora Tezi, Niğde.

Feick, L. F., \& Price, L. L. (1987). The market maven: A diffuser of marketplace information. The Journal of Marketing, 51, 83-97.

Goyette, I., Ricard, L., Bergeron, J., \& Marticotte, F. (2010). e-wom Scale: Word-of-mouth measurement scale for eservices context. Canadian Journal of Administrative Sciences/Revue Canadienne des Sciences de l'Administration, 27(1), 5-23.

Groeger, L., \& Buttle, F. (2014). Word-of-mouth marketing: Towards an improved understanding of multi-generational campaign reach. European Journal of Marketing, 48(7/8), 1186-1208.

Güler, E. G., \& Ülker, E. (2010). Politik pazarlama ve örnek bir olay incelemesi: Barack Obama. e-Journal of New World Sciences Academy, 5(2), 93-107.

Gülsünler, M. E. (2014). Siyasal iletişimde viral pazarlama: Kuramsal bir çerçeve. Selçuk Iletişim, 8(3), 76-91.

Harris, P. (2001). Machiavelli, political marketing and reinventing government. European Journal of Marketing, 35(9/10), 1136-1154.

Henneberg, S. C. (2004). The views of an advocatus dei: Political marketing and its critics. Journal of Public Affairs: An International Journal, 4(3), 225-243.

Henneberg, S. C., \& O'Shaughnessy, N. J. (2009). Political relationship marketing: Some macro/micro thoughts. Journal of Marketing Management, 25(1-2), 5-29. 
Heywood, A. (2006). Siyaset. (Çev. B.B. Özipek, B. Şahin, M. Yıldız, Z. Kopuzlu, B. Seçilmişoğlu \& A. Yayla) (Ed.) B. Kalkan, Ankara: Liberte Yayınları.

Hopkins, D. (2013). Political ads: Not as powerful as you (or politicians) think. Wonkblog. http://www.washingtonpost.com/blogs/wonkblog/wp/2013/01/20/political-ads-not-as-powerful-as-you-orpoliticians-think/ (Accessed, 7 February 2018).

Iyer, P., Yazdanparast, A., \& Strutton, D. (2017). Examining the effectiveness of wom/e-wom communications across age-based cohorts: Implications for political marketers. Journal of Consumer Marketing, 34(7), 646-663.

İslamoğlu, A. H. (2002). Siyaset pazarlaması toplam kalite yaklaşımı. İstanbul: Beta Yayınları.

Kalender, A. (2005). Siyasal iletişim: Seçmenler ve ikna stratejileri. Konya: Çizgi Yayınevi.

Karagöz, Y. (2016). SPSS ve amos 23 uygulamalı istatistiksel analizler. Ankara: Nobel Akademik Yayıncılık.

Kırım, A. (2007). Mor ineğin akıllısı: İşinizi farkıılaştırmanın kitabı. İstanbul: Sistem Yayıncılık.

Kotler, P. (1975). Overview of political candidate marketing. Advances in Consumer Research, 2, 761-769.

Lees-Marshment, J. (2001). The marriage of politics and marketing. Political Studies, 49(4), 692-713.

Liang, S. W. J., Ekinci, Y., Occhiocupo, N., \& Whyatt, G. (2013). Antecedents of travellers electronic word-of-mouth communication. Journal of Marketing Management, 29(5-6), 584-606.

Lock, A., \& Harris, P. (1996). Political marketing-Vive la différence. European Journal of Marketing, 30(10/11), 14-24.

Niffenegger, P. B. (1989). Strategies for success from the political marketers. The Journal of Consumer Marketing, 6(1), 45-51.

O'cass, A. (2002). A micromodel of voter choice: Understanding the dynamics of australian voter characteristics in a federal election. Psychology\&Marketing, 19(12), 1025-1046.

O'Cass, A., \& Pecotich, A. (2005). The dynamics of voter behavior and influence processes in electoral markets: A consumer behavior perspective. Journal of Business Research, 58(4), 406-413.

Orel, F. D., \& Nakiboğlu, B. (2010). Genç seçmenlerin oy tercihlerinde politik pazarlama faaliyetlerinden etkilenme düzeyleri. Finans Politik \& Ekonomik Yorumlar Dergisi, 47, 65-78.

Özyer, G. N. (2015). Marka aşkının marka sadakati ve ağızdan ağıza pazarlamaya etkisi: Pilot bir araştırma. Marmara Üniversitesi Sosyal Bilimler Enstitüsü, Yüksek Lisans Tezi, İstanbul.

Podoshen, J. (2008). The african american consumer revisited: Brand loyalty, word of mouth and the effects of the black experience. Journal of Consumer Marketing, 25(4), 211-222.

Polat, C. (2015). Siyasal pazarlama ve iletişim. Ankara: Nobel Yayın Dağıtım.

Polat, C., \& Kütler, B. (2008). Genç seçmenler gözüyle siyasal ürün (siyasi lider) özellikleri: Ankara'daki üniversite öğrencileri üzerine bir çalışma. Uluslararası Insan Bilimleri Dergisi, 5(1), 1-31.

Polat, C., Gürbüz, E., \& İnal, M.E. (2004). Hedef seçmen: Siyasal pazarlama yaklaşımı. Ankara: Nobel Yayın Dağıtım.

Reeves, P., \& De Chernatony, L. (2009, February). Political brand choice in britain. 6th Annual Political Marketing Conference London.

Richey, S. (2008). The autoregressive influence of social network political knowledge on voting behaviour. British Journal of Political Science, 38(3), 527-542.

Scammell, M. (1999). Political marketing: Lessons for political science. Political Studies, 47(4), 718-739.

Sekaran, U. (2003). Research methods for business: A skill building approach. New Jersey: John Wiley\&Sons Inc.

Skoric, M., Poor, N., Achananuparp, P., Lim, E. P., \& Jiang, J. (2012). Tweets and votes: A study of the 2011 singapore general election. 45th Hawaii International Conference on IEEE Hawai.

Tan, A. (1998). Politik pazarlama ve kahramanmaraşörneği. Cumhuriyet Üniversitesi Sosyal Bilimler Enstitüsü, Doktora Tezi, Sivas.

Tan, A. (2002). Illke ve uygulamalarıla politik pazarlama. İstanbul: Papatya Yayıncılık.

Van Steenburg, E. (2015). Areas of research in political advertising: A review and research agenda. International Journal of Advertising, 34(2), 1-37.

Waller, D. S. (1995). A proposed model of political communication: Expanding the communication model to incorporate multiple senders/receivers. Journal of Marketing Communications, 1(4), 209-219.

Winchester, T., Hall, J., \& Binney, W. (2016). Conceptualizing usage in voting behavior for political marketing: An application of consumer behavior. Journal of Political Marketing, 15(2-3), 259-284 
Wring, D. (1997). Reconciling marketing with political science: Theories of political marketing. Journal of Marketing Management, 13(7), 651-663.

Yılmaz, E. (2011). Sağlık hizmetlerinde ağızdan ağıza pazarlama. Marmara Sosyal Araştırmalar Dergisi, 1, 1-19.

Yüksek Seçim Kurulu. http://www.ysk.gov.tr/ysk (Accessed, 8 June 2016). 